\title{
Shifts in Growth Responses to Climate and Exceeded Drought-Vulnerability Thresholds Characterize Dieback in Two Mediterranean Deciduous Oaks
}

\author{
Raúl Sánchez-Salguero ${ }^{1,2, *,+}+\mathbb{C}$, Michele Colangelo ${ }^{2,3,+} \oplus$, Luis Matías ${ }^{4}{ }^{\oplus}$, Francesco Ripullone ${ }^{3}$ \\ and J. Julio Camarero ${ }^{2}$ (i) \\ 1 Depto. Sistemas Físicos, Químicos y Naturales, University Pablo de Olavide, Crta. Utrera km. 1, \\ E-41013 Sevilla, Spain \\ 2 Instituto Pirenaico de Ecología (IPE-CSIC), Avda. Montañana 1005, E-50059 Zaragoza, Spain; \\ michelecolangelo3@gmail.com (M.C.); jjcamarero@ipe.csic.es (J.J.C.) \\ 3 School of Agricultural, Forest, Food and Environmental Sciences, University Basilicata, \\ I-85100 Potenza, Italy; francesco.ripullone@unibas.it \\ 4 Department of Plant Biology \& Ecology, University of Seville, Av. Reina Mercedes s/n, 41012 Seville, Spain; \\ lmatias@us.es \\ * Correspondence: rsanchez@upo.es; Tel.: +34-954349535 \\ + Co-first authors.
}

Received: 9 May 2020; Accepted: 23 June 2020; Published: 27 June 2020

check for updates

\begin{abstract}
Drought stress has induced dieback episodes affecting many forest types and tree species worldwide. However, there is scarce information regarding drought-triggered growth decline and canopy dieback in Mediterranean deciduous oaks. These species face summer drought but have to form new foliage every spring which can make them vulnerable to hotter and drier conditions during that season. Here, we investigated two stands dominated by Quercus frainetto Ten. and Quercus canariensis Willd. and situated in southern Italy and Spain, respectively, showing drought-induced dieback since the 2000s. We analyzed how radial growth and its responses to climate differed between non-declining (ND) and declining (D) trees, showing different crown defoliation and coexisting in each stand by: (i) characterizing growth variability and its responsiveness to climate and drought through time, and (ii) simulating growth responses to soil moisture and temperature thresholds using the Vaganov-Shashkin VS-lite model. Our results show how growth responsiveness to climate and drought was higher in D trees for both oak species. Growth has become increasingly limited by warmer-drier climate and decreasing soil moisture availability since the 1990s. These conditions preceded growth drops in D trees indicating they were more vulnerable to warming and aridification trends. Extremely warm and dry conditions during the early growing season trigger dieback. Changes in the seasonal timing of water limitations caused contrasting effects on long-term growth trends of D trees after the 1980s in Q. frainetto and during the 1990s in Q. canariensis. Using growth models allows identifying early-warning signals of vulnerability, which can be compared with shifts in the growth responses to warmer and drier conditions. Our approach facilitates establishing drought-vulnerability thresholds by combining growth models with field records of dieback.
\end{abstract}

Keywords: dendroecology; tree-rings; VS-lite; Quercus frainetto; Quercus canariensis; tree rings

\section{Introduction}

Drought stress due to climate warming and higher precipitation variability has been considered among the main abiotic causes of forest dieback in the Mediterranean regions of southern Europe [1,2]. Climate warming can influence forests by modifying the start (e.g., earlier bud bursting) and 
duration of the growing season (e.g., delayed leaf fall), but also by amplifying drought stress rising evapotranspiration rates [3-5]. Thus, understanding the vulnerability of forest ecosystems to warming and drier conditions is crucial to ensure early decision of adaptive management measures, particularly in drought-sensitive tree species [6]. Forest dieback episodes have reported widespread growth reductions, loss of tree vigor (e.g., canopy dieback), and increasing tree mortality [7] in different tree species and forest biomes [8]. The Mediterranean Basin is one of the major forest-dieback hotspots where an increasing vulnerability to climate change has manifested [9].

Forest dieback has been observed since the end of the 20th century in drought-prone Mediterranean oak forests [10-15]. These dieback events were associated to extreme climatic events as droughts, but also involved fungal pathogens and pests as secondary stress factors [5,16]. Oaks are among the most important tree species in terms of cultural, economic, and ecological values in Mediterranean regions $[17,18]$. Under forecasted longer and more intense hotter droughts, Mediterranean oaks, and specially anisohydric ring-porous, winter-deciduous species, are prone to showing an increasing risk of dieback and mortality due to hydraulic failure or carbon starvation [19]. In these species, drought impairs their photosynthetic activity, reducing their primary and secondary growth and triggering leaf shedding $[20,21]$. Importantly, these species have to rebuild new foliage every early spring before summer drought starts which makes them very susceptible to dry conditions from the previous winter to early summer [22]. Furthermore, the impact of drought-triggered oak dieback can be modulated by other intrinsic (e.g., tree height, competition) and extrinsic (e.g., soil conditions, microclimate) factors $[14,15,23,24]$. However, little is known about the long-term responses to climate and related vulnerability thresholds in co-occurring trees of Mediterranean deciduous oak species showing different canopy dieback intensity after drought.

Here we follow a retrospective approach based on dendroecological analyses in two ring-porous, winter-deciduous oak species showing dieback in southern Italy (Quercus frainetto Ten.) [14] and southern Spain (Quercus canariensis Willd.). We used dendrochronology to characterize shifts in long-term growth responses to climate and drought, and to define temperature and water availability thresholds in order to detect the onset of growth decline preceding canopy dieback. The studied oak species are particularly sensitive to increasing aridity and have been still scarcely studied using dendroecologcal approaches $[5,14,15,25,26]$. The comparison of growth responses to climate of coexisting trees with different drought impact in terms of canopy dieback could advance our knowledge on the vulnerability thresholds to forecasted warming- and drought-related dieback and mortality processes.

We hypothesize that (i) declining (D) trees show higher sensitivity to minimum and optimal temperature and water availability thresholds for growth, and (ii) that growth of D trees diverged from non-declining (ND) trees several decades before the onset of canopy dieback $[27,28]$. To compare the growth responses to climate over the growing season, we used the Vaganov-Shashkin-Lite model (hereafter VS-lite), a well-validated forward model of tree-ring formation [29-31]. This model simulates monthly growth responses to temperature and precipitation, which can help to understand the vigor-dependent growth responses thresholds of $\mathrm{D}$ and $\mathrm{ND}$ trees to climate warming and drought.

We evaluate how climate modulates growth of D and ND oak individuals in sites suffering drought-induced dieback by assessing climate-growth responses and using the VS-lite model. Our specific aims are (1) to compare the climate-growth responses in coexisting D and ND trees of two Mediterranean oak species, (2) to analyze the drought-induced changes in growth dynamics of ND and D trees, and (3) to characterize the shifts in growth responses thresholds across time using the VS-lite model. We hypothesize that (i) ND trees should show less water limitations and lower climate sensitivity prior to the dieback onset than D trees, (ii) shifts in vulnerability thresholds should determine the onset of the growth decline, and (iii) ND trees should be less negatively affected by drought stress than $\mathrm{D}$ trees, since $\mathrm{D}$ trees are assumed to be less drought tolerant by presenting a less conservative stomatal regulation and, possibly, a xylem more vulnerable to embolism [15,32]. 


\section{Materials and Methods}

\subsection{Study Sites, Species, and Climate}

We selected two forests with recent drought-induced dieback located in southern Italy (Q.frainetto in San Paolo Albanese, Basilicata region) and in southern Spain (Q. canariensis in Gamir, "Los Alcornocales" Natural Park, Andalusia) (Table 1). In these sites, mean oak density values are 348 and 54 individuals $\mathrm{ha}^{-1}$, respectively.

Table 1. Characteristics of the sampled Mediterranean oak (Quercus frainetto and Quercus canariensis) forests.

\begin{tabular}{ccc}
\hline Variable & Q. frainetto & Q. canariensis \\
\hline Site name & San Paolo Albanese & Gamir-Alcornocales \\
Latitude $(\mathrm{N})$ & $40^{\circ} 00^{\prime} 50^{\prime \prime}$ & $36^{\circ} 34^{\prime} 12^{\prime \prime}$ \\
Longitude $(\mathrm{W} / \mathrm{E})$ & $16^{\circ} 21^{\prime} 01^{\prime \prime} \mathrm{E}$ & $5^{\circ} 32^{\prime} 02^{\prime \prime} \mathrm{W}$ \\
Elevation range (m a.s.l.) & $850-1170$ & $490-530$ \\
Aspect & $\mathrm{SW}$ & $\mathrm{SE}$ \\
Slope $(\%)$ & $25-30$ & 15 \\
Annual precipitation $(\mathrm{mm})$ & $584 \pm 17$ & $560 \pm 23$ \\
Spring precipitation $(\mathrm{mm})$ & $132 \pm 6$ & $141 \pm 8$ \\
Mean temperature $\left({ }^{\circ} \mathrm{C}\right)$ & $14.1 \pm 0.5$ & $16.4 \pm 0.1$ \\
Mean spring temperature $\left({ }^{\circ} \mathrm{C}\right)$ & $11.9 \pm 0.2$ & $14.6 \pm 0.2$ \\
\hline
\end{tabular}

The Hungarian oak (Quercus frainetto Ten.) is a large deciduous tree native from the Balkan Peninsula, northwest Turkey, and southern Italy (Figure 1). It is light-demanding and may reach heights up to $30 \mathrm{~m}$ under optimal environmental conditions [33]. Hungarian oak growth is sensitive to dry late spring and summer conditions [14,34]. The Algerian oak (Quercus canariensis Wild.) is native to southern Portugal, Spain, Tunisia, Algeria, and Morocco. It inhabits sites with acid soils in the most humid and warm parts of the Mediterranean coastal regions of the Iberian Peninsula and Northern Africa [35]. Algerian oak growth is sensitive to dry and warm late spring conditions [26].

Climate in the study areas is Mediterranean with wet and mild winters and dry and warm summers (Figure 1, Table 1). Monthly climate data to characterize both study areas were retrieved for the period 1950-2017 from the E-OBS v.20e $0.25^{\circ}$-gridded database, which has been subjected to previous quality-check and homogeneity tests [36]. The warmest and coldest months are July (mean temperature of $22-24^{\circ} \mathrm{C}$ ) and January (mean temperature of $9-10^{\circ} \mathrm{C}$ ), respectively; whereas the wettest months are November in Italy $(98 \mathrm{~mm})$ and December in Spain $(90 \mathrm{~mm})$; and the driest month is July (17 and $0 \mathrm{~mm}$ in Italy and Spain, respectively). Drought occurs in both sites from June to August (Figure 1).

Monthly climate data were converted into seasonal values (December, January and February, winter-WI; March, April and May, spring-SP; June, July and August, summer-SU; September, October and November, autumn-AU) either by averaging (temperature) or summing (precipitation). 


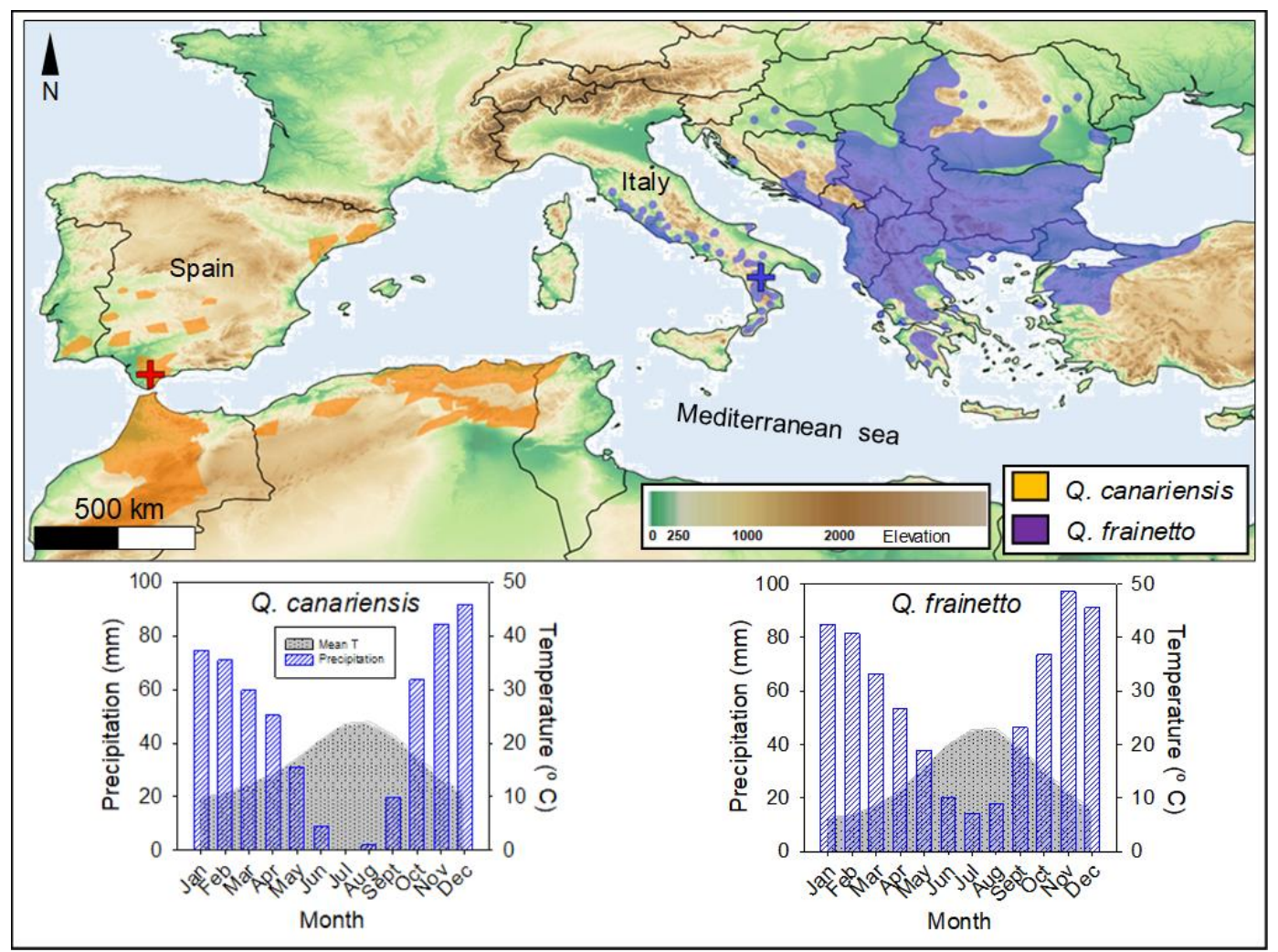

Figure 1. Location of the study sites in southern Spain (Q. canariensis, red cross) and southern Italy ( $Q$. frainetto, blue cross). The background shows the elevation and the distribution of the species in the Mediterranean Basin (Q. canariensis from [37], Q. frainetto from [38]). The lower plots show the climatic diagrams for each study site.

\subsection{Dendrochronological Methods}

We sampled tree cores in pairs of neighbor dominant trees located 5-10 m apart, with contrasting vigor status: declining (D trees, crown defoliation $>50 \%$ ) and non-declining (ND trees, crown defoliation $<25 \%$ ). We sampled from 11 to 39 trees per vigor class in each site during summer (Q. frainetto) and winter (Q. canariensis) 2017. Crown transparency was estimated by a visual assessment performed by two independent observations on the same tree using binoculars [39]. We measured the diameter at breast height (DBH) and height for each tree using metric tapes and a laser rangefinder, respectively. Tree cores were extracted at $1.3 \mathrm{~m}$ using Pressler increment borer (Table 2), air dried, and sanded until tree rings became clearly visible [40]. Wood samples were visually cross-dated and measured with precision of $0.01 \mathrm{~mm}$ using a binocular microscope coupled to a semiautomatic device (LINTAB ${ }^{\mathrm{TM}}$, Rinntech, Heidelberg, Germany). The COFECHA program was used to evaluate the quality of the visual cross-dating of tree-ring series [41]. To estimate age at $1.3 \mathrm{~m}$ we counted the number of annual rings. In case of cores without pith, the number of missing rings was estimated by fitting a template of concentric circles with known radii to the innermost rings.

To evaluate climate-growth relationships, first we removed age- and size-related long-term trends of tree-ring width series by converting raw tree-ring width series into ring-width indices (TRWi). This was done by fitting a 30-year long spline to raw data to preserve high-frequency growth variability, and then dividing observed by fitted values to obtain dimensionless, standardized ring-width indices [40]. In addition, an autoregressive model was applied to each individual detrended series to remove the first-order autocorrelation. Finally, a biweight robust mean was computed to obtain the residual chronology (mean of pre-whitened, indexed series) for D and ND trees.

To assess the quality of these mean tree-ring series (two per site) we calculated dendrochronological statistics for the common period 1950-2016: the first-order autocorrelation of ring-width data (AC), 
the mean sensitivity of ring-width indices (MS), which assesses the relative variability in width between consecutive rings, the mean correlation between individuals (IC) [42]; and the expressed population signal (EPS), which measures the statistical quality of the mean site chronology compared to a perfect infinitely replicated chronology [43]. To quantify if D and ND chronologies were more or less synchronized through time, 20-year long moving correlations overlapping by one year were calculated between them in each site.

Table 2. Growth data, mean $( \pm \mathrm{SE})$ values of diameter at breast height $(\mathrm{DBH})$, height $(\mathrm{H})$, tree age at 1.3 $\mathrm{m}$, and dendrochronological statistics from the residual ring-width chronologies of $Q$. frainetto in Italy and Q. canariensis in Spain for the common period 1950-2016.

\begin{tabular}{ccccc}
\hline \multirow{2}{*}{ Variable } & \multicolumn{2}{c}{ Q. frainetto } & \multicolumn{2}{c}{ Q. canariensis } \\
\cline { 2 - 5 } & ND & D & ND & D \\
\hline DBH (cm) & $32.3 \pm 0.8$ & $31.9 \pm 0.9$ & $48.5 \pm 1.8 \mathrm{~b}$ & $55.8 \pm 5.5 \mathrm{a}$ \\
H (m) & $14.3 \pm 0.6 \mathrm{a}$ & $9.9 \pm 0.5 \mathrm{~b}$ & $11.7 \pm 0.2$ & $11.1 \pm 0.5$ \\
Defoliation (\%) & $8 \pm 0.8 \mathrm{~b}$ & $66 \pm 2.8 \mathrm{a}$ & $10 \pm 2 \mathrm{~b}$ & $73 \pm 4 \mathrm{a}$ \\
No. trees/No. radii & $24 / 34$ & $27 / 34$ & $11 / 11$ & $11 / 9$ \\
Age (years) 1,2 & $140 \pm 3 \mathrm{a}$ & $132 \pm 6 \mathrm{~b}$ & $107 \pm 4 \mathrm{~b}$ & $117 \pm 5 \mathrm{a}$ \\
Timespan & $1851-2016$ & $1831-2016$ & $1897-2017$ & $1873-2017$ \\
RW SE (mm) & $0.70 \pm 0.01 \mathrm{a}$ & $0.61 \pm 0.02 \mathrm{~b}$ & $1.48 \pm 0.04 \mathrm{a}$ & $1.35 \pm 0.05 \mathrm{~b}$ \\
AC & $0.75 \pm 0.01$ & $0.77 \pm 0.02$ & $0.62 \pm 0.05$ & $0.68 \pm 0.06$ \\
MS & $0.23 \pm 0.02$ & $0.23 \pm 0.01$ & $0.29 \pm 0.02$ & $0.32 \pm 0.01$ \\
IC & $0.51 \pm 0.02$ & $0.46 \pm 0.02$ & $0.47 \pm 0.03 \mathrm{a}$ & $0.36 \pm 0.09 \mathrm{~b}$ \\
EPS & 0.951 & 0.928 & 0.930 & 0.898
\end{tabular}

\footnotetext{
1 Variables abbreviations: Raw data: RW: tree-ring width, AC, first-order autocorrelation. Residual chronologies: MS, mean sensitivity; IC, mean inter-correlation among trees; EPS, expressed population signal. ${ }^{2}$ Different letters indicate significantly $(p<0.05)$ different mean values between ND and D oaks within each site based on Mann-Whitney $U$ tests.
}

\subsection{Climate-Growth Relationships and Statistical Analyses}

We quantified the climate-growth associations for the common and best-replicated period 1950-2016 using Pearson correlations. Correlations were calculated considering monthly and seasonal climate variables (mean temperature, accumulated precipitation). The window of analyses included from previous August to current October based on previous studies of the two oak species $[5,14,15,26]$. Correlations were calculated on mean, pre-whitened TRWi series of ND and D trees (residual chronologies) but also considering individual series to test if ND and D trees were distinctly impacted by climate. To assess whether these relationships changed through time in D and ND trees, we calculated 20-year moving correlations overlapping by one year, between D and ND series and also with climate variables significantly $(p<0.01)$ correlated with TRWi. Comparisons of variables between D and ND trees were assessed using Mann-Whitney $U$ tests for non-parametric analyses and one-way ANOVAs for variables following normality. All the tree-ring analyses were run with $d p l R$ [44], except climate-growth relationships which were calculated using the treeclim package [45]. All analyses were done in the R environment [46].

\subsection{VS-Lite Forward Growth Model}

We used the VS-lite model to assess differences in climatic controls of tree growth of D and ND trees. The model is based on the principle of limiting factors affecting tree-ring formation [29], and simulates anomalies of the standardized tree-ring width series (TRWi) based on the minimum growth response to temperature $(g T)$ and soil moisture $(g M)$ at monthly scale. The daily solar radiation is also considered by insolation $(g E)$ estimated by site latitude and did not vary from year to year [30,31]. We used the VS-lite model to simulate growth though Bayesian estimations using two parameters: first, the threshold below which growth will not occur ( $T_{1}$ for temperature, $M_{1}$ for soil moisture), and, second, the threshold above which growth is not limited by this climate factors $\left(\mathrm{T}_{2}\right.$ for temperature, 
$\mathrm{M}_{2}$ for soil moisture). The growth responses to temperature $(g T)$ and soil moisture $(g M)$ are simulated by the calibration on these parameters. We simulated VS-lite chronologies for the period 1950-2016 using the calibrated parameter for each D and ND tree of each species. We evaluated the assumption of uniform priors for the growth function parameters (with independent and normally distributed errors for TRWi values) by 13,000 iterations using three parallel chains and a white Gaussian noise model error [31]. To test the model performance, we divided the study period in two sub-periods to cross-validate changes into periods 1950-1983 and 1984-2016. To estimate monthly soil moisture from temperature and total precipitation, the VS-lite model uses the empirical Leaky Bucket Model of hydrology [47]. For the entire period 1950-2016, the growth parameters were estimated using annual intervals to produce the best correlation between observed and simulated chronologies. For this study the specific parameters (e.g., runoff, root depth, growing season length, etc.) were taken from previous studies $[5,15,26,30,31,48-51]$. Snow dynamics were not explicitly considered in the model and all the precipitation was assumed to be liquid, which is plausible for the study sites where snow precipitation is rare in $Q$. canariensis sites and scarce in $Q$. frainetto forests.

\section{Results}

\subsection{Climate Trends, Size, and Growth Patterns}

Mean annual temperature in both study areas showed significant $(p<0.05)$ and positive trends since the 1970s, particularly in the Q. canariensis site (mean rate $+0.0{ }^{\circ} \mathrm{C}$ year $^{-1}$ ). All months except November showed significant and positive trends in mean temperature in the $Q$. canariensis site, and spring and summer temperature in the Q. frainetto site. Seasonal precipitations did not show a significant trend since the 1950s (Figure 2). Only March for $Q$. canarienesis showed a significant negative $(r=-0.27)$ trend in precipitation. Lastly, the spring and summer precipitations were low during 1990 (117 mm), 1997 (132 mm), 2000-2001 (100 mm on average) in the Q. frainetto site, and 1985 (93 mm), 1994-1995 (69 mm on average), 1999 (78 mm), 2005 (60 mm) in the Q. canariensis site (Figure 2).

In Q. frainetto, $\mathrm{ND}$ trees were taller and their stems were slightly thicker than $\mathrm{D}$ trees, in contrast to Q. canariensis where $\mathrm{D}$ trees had thicker stems (Table 2). ND trees were older than $\mathrm{D}$ trees in $Q$. frainetto but not in Q. canariensis (Table 2). The mean inter-correlation (IC) with the site chronologies was higher in $\mathrm{D}$ trees in both sites indicating a higher coherence and higher responsiveness to climate. ND and $\mathrm{D}$ trees had similar values of first-order autocorrelation (AC), whereas mean sensitivity (MS) was slightly higher in ND trees. In both sites the EPS for D and ND trees was above the 0.85 threshold after 1920s in Q. canariensis and after 1870s in Q. frainetto (Table 2).

Mean radial-growth rates were higher in ND than in D trees in both species for the common period 1950-2016 (Table 2). Tree-ring width increased from the 1950s to late 1960s (more in ND trees), but decreased after the 1970s in Q. frainetto (Figure 3). In Q. frainetto, growth of ND (positive trend) and $\mathrm{D}$ (negative trend) trees diverged after the mid of 1990s. In Q. canariensis growth showed higher rates in ND than in D trees in the 1960s and 1970s with a pronounced growth reduction after the late 1990s, which was higher in D than in ND trees (Figure 3). Regarding the moving correlations between ND and D chronologies, it decreased since the mid 1980s in Q. frainetto, but increased after the 2000s in Q. canariensis.

\subsection{Climate-Growth Associations}

Warm spring conditions negatively affected $Q$. frainetto growth, with more negative correlations in $\mathrm{D}$ than in ND trees $(F=11.87, p<0.01)$, whereas $Q$. canariensis growth negatively responded to warm May and previous autumn (October) conditions, particularly D trees (Figure 4). Wet previous winter and spring (April) conditions enhanced $Q$. frainetto growth of both vigor classes, with slightly higher sensitivity in D trees, whilst wet current May conditions improved growth in Q. canariensis, regardless crown defoliation, and also a previous wet October but only in ND trees (Figure 4). 
Moving correlations between TRWi and relevant climate variables showed a shift in $Q$. frainetto in the 1990s for spring temperature, which has become a more important constraint of growth in D than in ND trees (Figure 5). The relationships with previous autumn precipitation increased after the 1980s with a shift from negative to positive values in both vigor classes, but showing higher correlations in $\mathrm{D}$ trees (Figure 5). In the same way, the influence of spring precipitation increased more in Q. canariensis $\mathrm{D}$ trees than in ND trees after the 1990s. Furthermore, May temperature has shifted from positive to significant negative correlations with growth in $Q$. canariensis $\mathrm{D}$ trees.
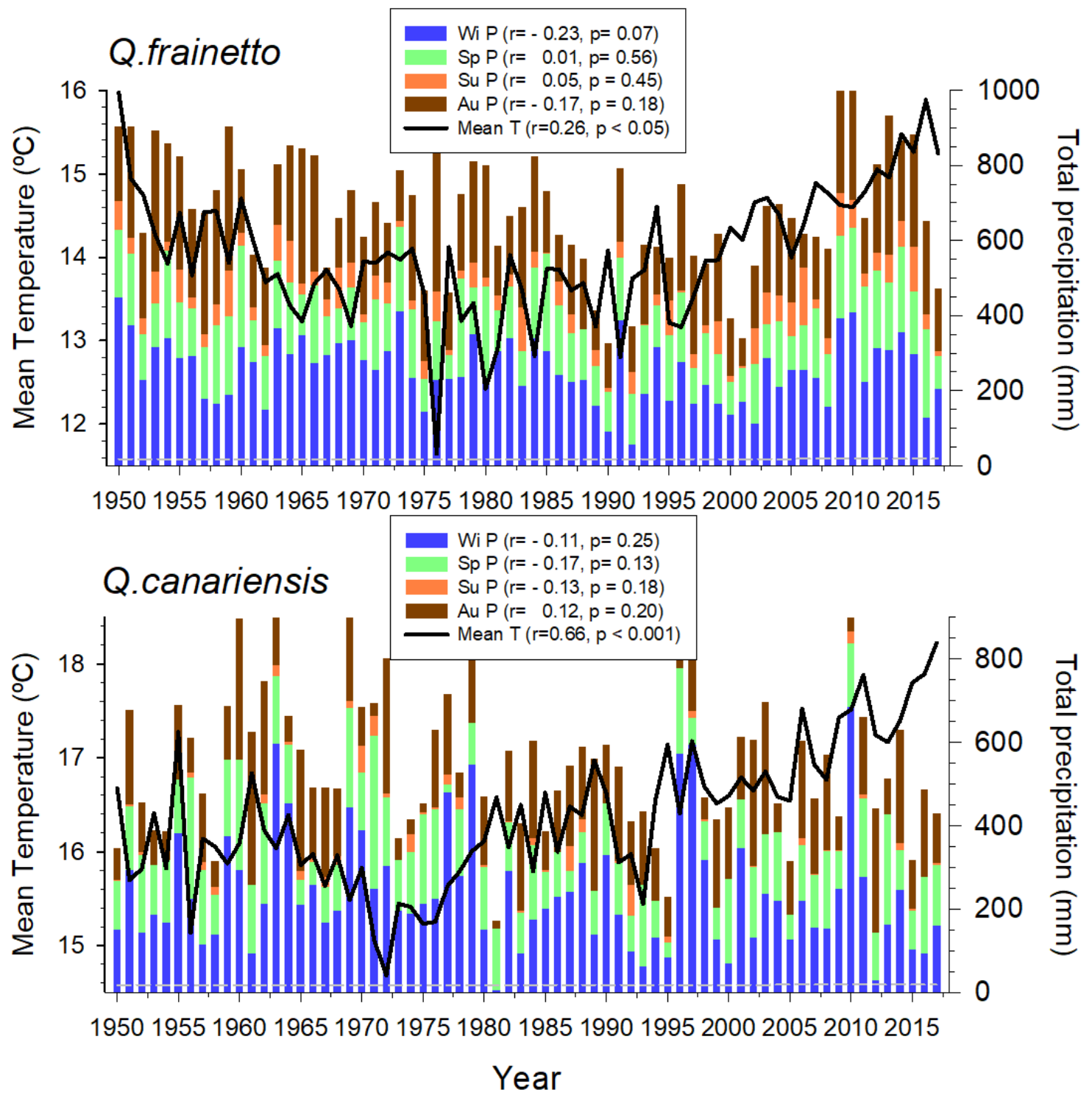

Figure 2. Total annual and seasonal (Wi, winter; $\mathrm{Sp}$, spring; $\mathrm{Su}$, summer; Au, autumn) precipitation (P) and mean annual temperature (Mean T) for the studied sites during the 1950-2017 period. The statistics show associations with time ( $r$, Pearson correlation coefficients; $p$, probability level). 


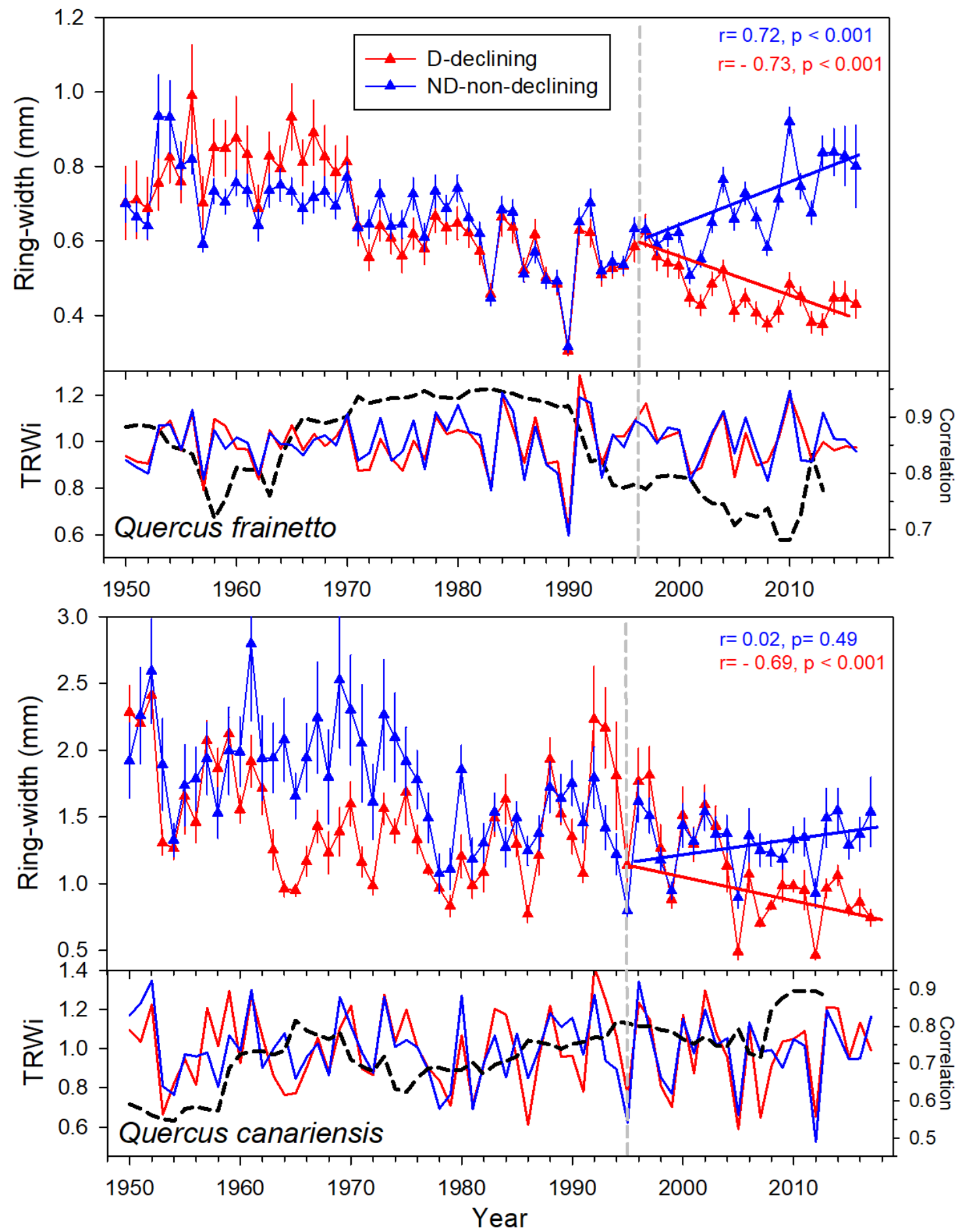

Figure 3. Tree-ring growth series of non-declining (ND, blue symbols and lines) and declining (D, red symbols and lines) oak trees in the two study sites from southern Italy ( $Q$. frainetto) and Spain (Q. canariensis), respectively. In the lower plots for each species, the lines show the residual chronologies (mean series of pre-whitened ring-width indices, TRWi). Tree-ring width values are means \pm SE. The vertical dashed lines indicate the year when tree-ring width of $\mathrm{D}$ and ND trees started to show significantly $(p<0.05)$ different trends (solid lines). The statistics show growth trends ( $r$, Pearson correlation coefficient; $p$, probability level). Temporal changes in moving correlations (dashed black lines) between $\mathrm{D}$ and ND chronologies are shown in the right $y$-axis. Moving correlations were calculated using 20-year long intervals shifted by one year for the period 1930-2016 (values are arranged for the last year of each 20-year interval). 


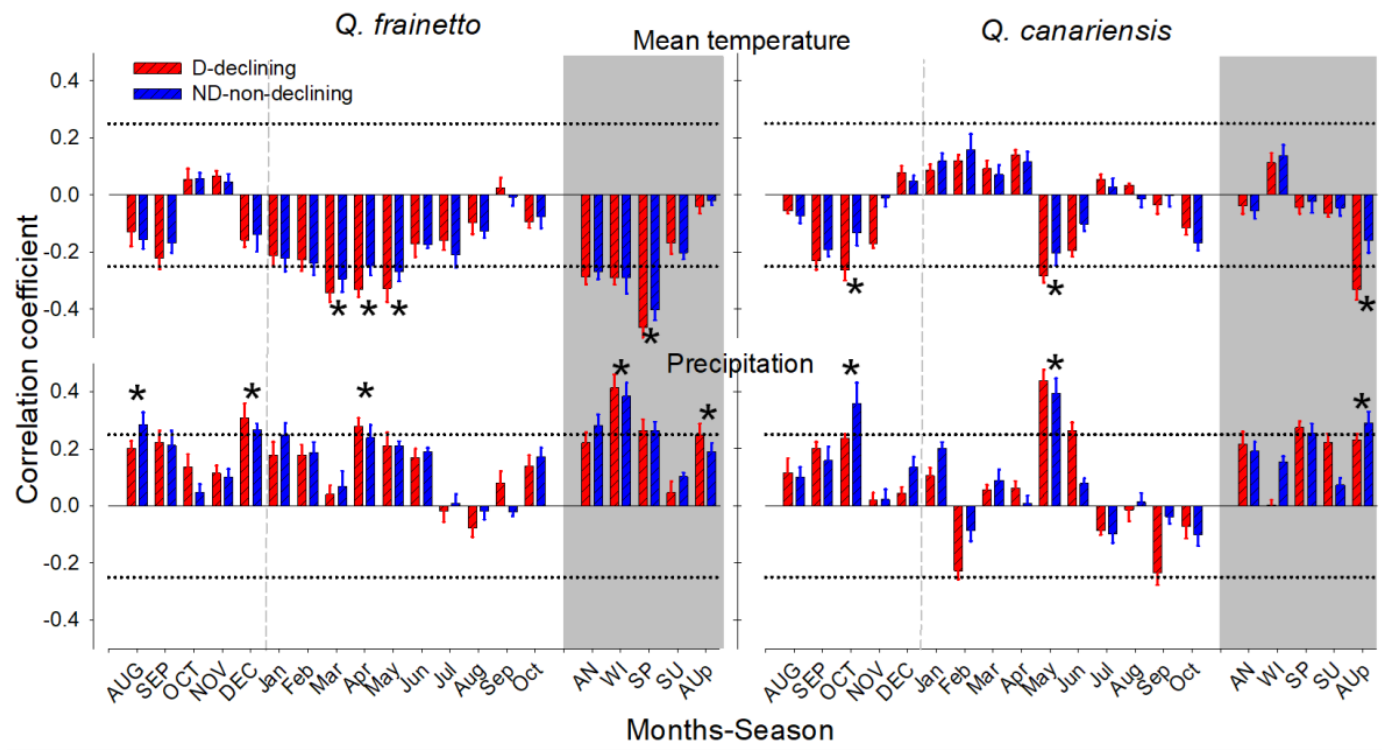

Figure 4. Climate-growth associations observed for declining (D, red bars) and non-declining (ND, blue bars) trees of $Q$. frainetto and $Q$. canariensis. Bars show Pearson correlations (means $\pm \mathrm{SE}$ ) obtained by relating monthly or seasonal climate variables (mean temperature and total precipitation) and individual series of ring-width indices, TRWi (residual chronologies). Uppercase and lowercase abbreviations correspond to months and seasons (grey areas) of the previous (August-December) and current (January-October) years, respectively. Correlations were also calculated considering annual (AN) and seasonal climate data (AUp, previous autumn; WI, winter; SP, spring; SU, summer). The dotted horizontal lines indicate the 0.05 significance level, and asterisks indicate significant $(p<0.05)$ differences found between correlations of $\mathrm{D}$ and ND trees for each species based on ANOVAs.
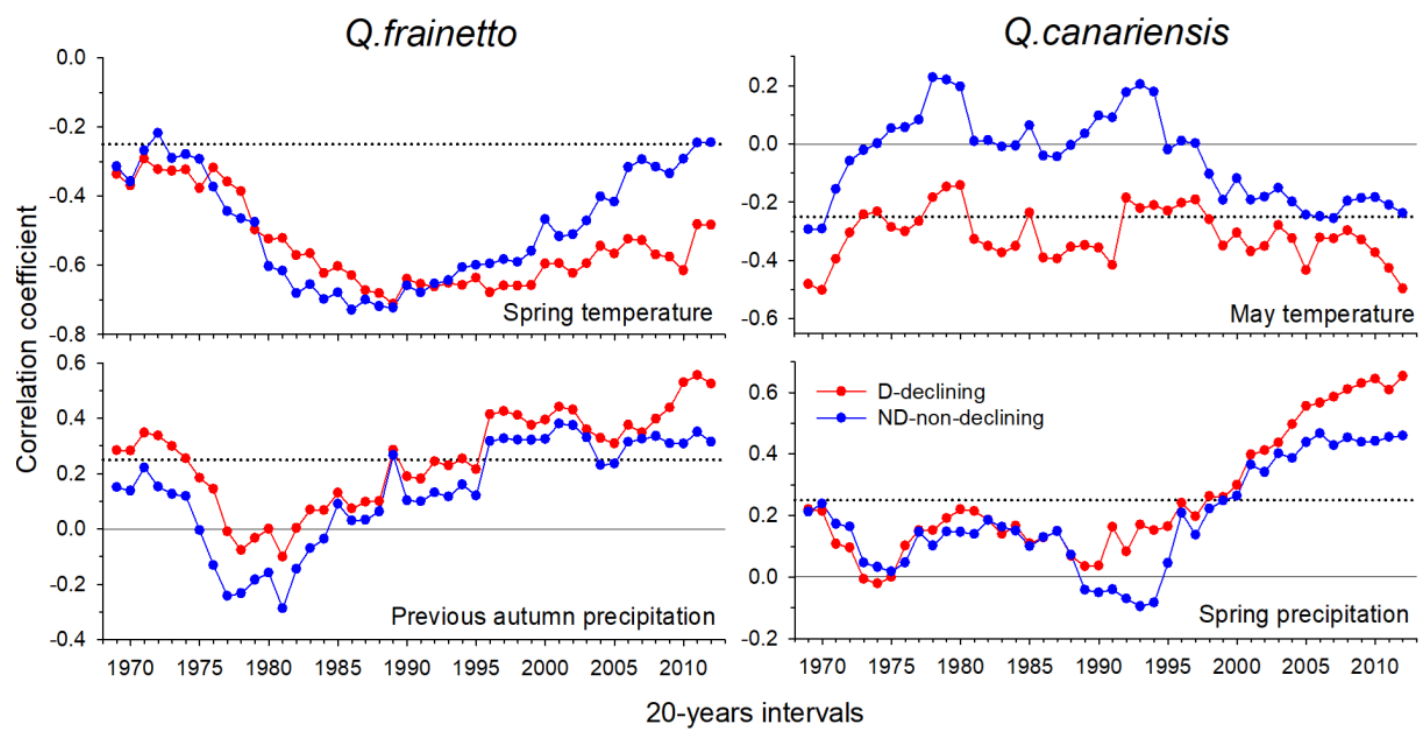

Figure 5. Temporal changes in correlation coefficients between selected climate variables (spring temperature and previous autumn precipitation for $Q$. frainetto; May temperature and spring precipitation for $Q$. canariensis) and residual chronologies of declining (D, red lines and symbols) and non-declining (ND, blue lines and symbols). Correlations were calculated using 20-year intervals shifted by one year for the period 1950-2016 (values are arranged for the last year of each 20-year long interval). Dotted horizontal lines indicate significant correlation coefficients $(p<0.05)$.

\subsection{Forward Growth Modeling for Oaks Dieback}

The comparison of mean growth response $(g T, g M)$ during the growing season between $\mathrm{D}$ and ND trees of both oak species showed longer seasons towards the early 21st century. The model indicated 
more pronounced soil-moisture limitations $(g M<g T)$ in D trees, but a lower soil-moisture peak in ND (Q. frainetto) and $\mathrm{D}$ (Q. canariensis) trees (Figure 6). In both oak species, the VS-lite model accurately tracked the year-to-year growth variability (TRWi) for $\mathrm{D}$ and ND trees. The growth in both species was limited by low temperatures $(g T<g M)$ at the beginning and the end of the growing season, with warmer conditions in D than in ND trees, and by reduced soil moisture availability $(g M<g T)$ during spring, summer, and autumn, with more lasting soil-moisture limitations in D than in ND trees for both species (Figure 6). The estimated temperature $\left(\mathrm{T}_{1}, \mathrm{~T}_{2}\right)$ and soil moisture thresholds $\left(\mathrm{M}_{1}, \mathrm{M}_{2}\right)$ for growth confirmed the highest sensitivity of $Q$. frainetto $\mathrm{D}$ trees to warm spring temperatures (maximum $\mathrm{T}_{1}$ value). In addition, $\mathrm{D}$ trees of both species showed higher soil moisture for optimal growth conditions $\left(\mathrm{M}_{2}\right)$, confirming the sensitivity of $\mathrm{D}$ trees to dry and warm conditions during the growing season (Figures 6 and 7). The optimal growth conditions $\left(T_{2}, M_{2}\right)$ during the 1950-1983 and 1984-2016 sub-periods confirmed the shift in growth responses to warm and dry climate conditions, again with a higher sensitivity of D trees in both species (Figure 7, Table 3). Consequently, growing conditions for $\mathrm{D}$ trees has sharply deteriorated because of increasing temperature and reduced soil water availability.

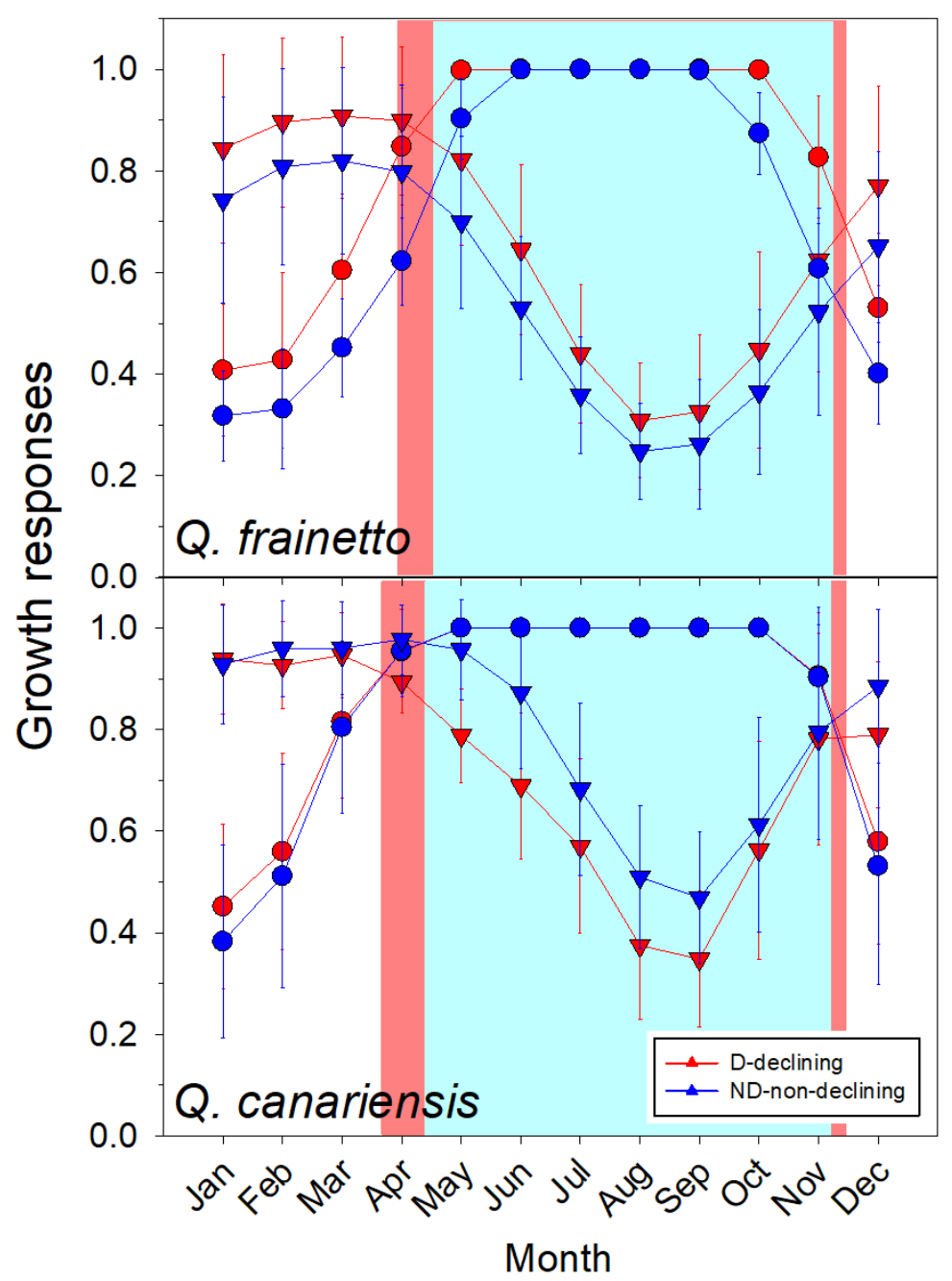

Figure 6. Simulated monthly growth response curves ( $g T, g M$; means $\pm S D$ ) of the two study oaks using the VS-Lite model for the period 1950-2016. The growth responses consider temperature ( $g T$, circles) and soil moisture limitations ( $g M$, downward triangles) for non-declining (ND, blue symbols and lines) and declining ( $\mathrm{D}$, red symbols and lines) trees. The blue and red areas indicate the estimated periods with soil moisture limitation for ND (blue) and D (red) trees, respectively. 


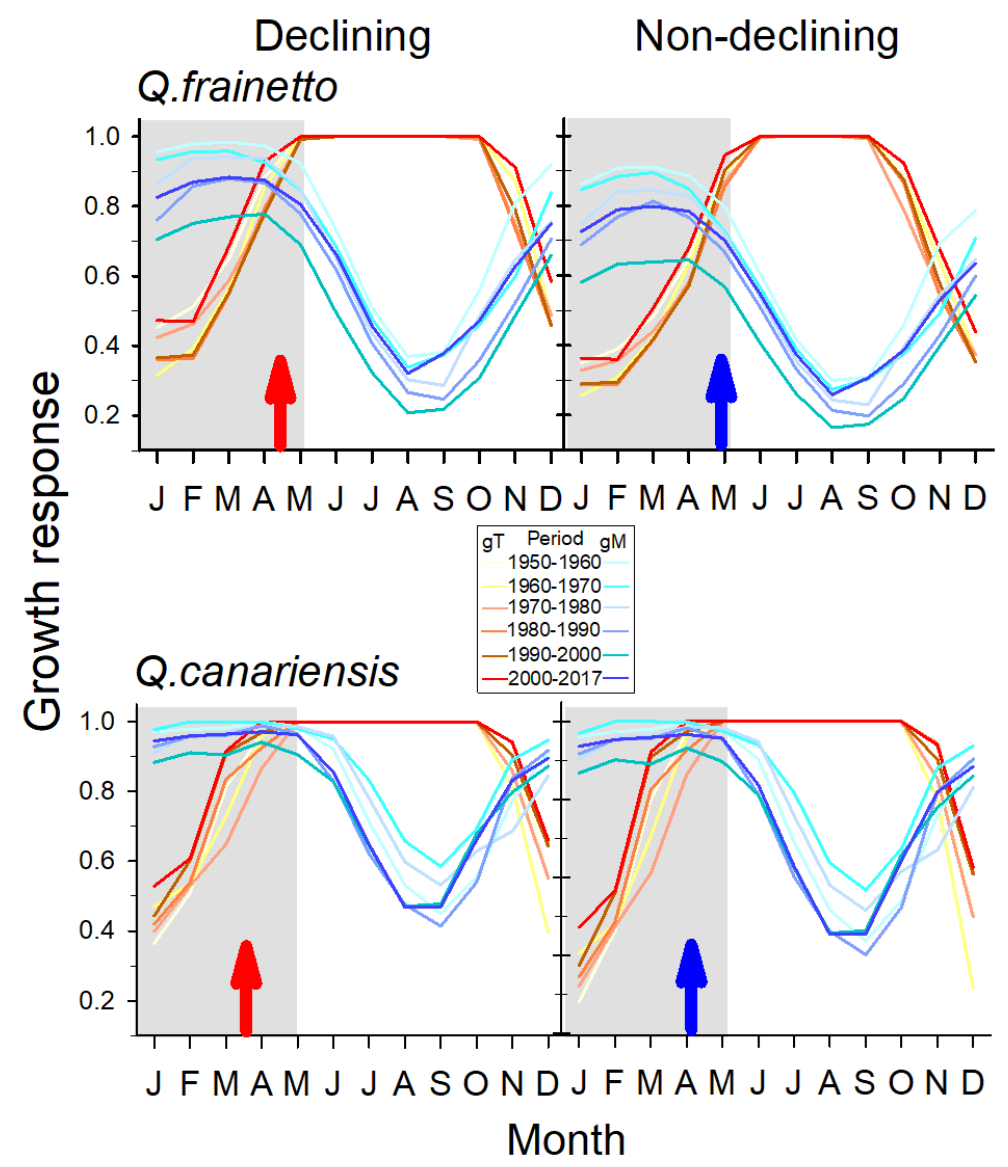

Figure 7. Temporal shifts in growth responses to temperature ( $g T$, red to yellow-tone lines) and soil moisture ( $g M$, blue-tone lines) averaged over decades (1950-1960, 1960-1970, 1970-1980, 1980-1990, 1990-2000) and the 2000-2017 period for declining (D) and non-declining (ND) oak trees. The arrows show the averaged estimated period with soil moisture below the minimum thresholds for growth $\left(\mathrm{M}_{1}\right.$, minimum soil moisture) in ND (blue arrows) and D (red arrows) trees. The parts of the onset of the growing season (grey boxes) with the most important changes in temporal thresholds of growth responses to air temperature and to soil moisture are emphasized. Note the increasingly hotter (higher $g T$ ) and drier (lower $g M$ ) limiting growth conditions during spring in both species.

Table 3. Pearson correlation coefficients $(r)$ calculated between mean series of ring-width indices (TRWi) and VS-lite ring width indices for the calibration period (1950-2016) and for the cross-validated sub-periods 1950-1983 and 1984-2016 [31]. Pearson correlation values ( $r$ ), always significant at the 0.05 level, are presented. Statistics of the Bayesian estimation of the growth response parameters $\left(\mathrm{T}_{1}, \mathrm{~T}_{2}\right.$, $\mathrm{M}_{1}$, and $\mathrm{M}_{2}$ for minimum and optimal temperature and soil moisture values, respectively, for the non-declining (ND) and declining (D) trees are presented.

\begin{tabular}{cccccc}
\hline \multirow{2}{*}{ Periods } & \multirow{2}{*}{ Variable } & \multicolumn{2}{c}{ Q.frainetto } & \multicolumn{2}{c}{ Q. canariensis } \\
\cline { 3 - 6 } & & $\mathbf{N D}$ & $\mathbf{D}$ & $\mathbf{N D}$ & $\mathbf{D}$ \\
\hline \multirow{3}{*}{$1950-2016$} & $r$ & 0.38 & 0.36 & 0.46 & 0.33 \\
& $\mathbf{T}_{\mathbf{1}} / \mathbf{T}_{\mathbf{2}}\left({ }^{\circ} \mathbf{C}\right)$ & $2.0 / 14.3$ & $2.6 / 11.3$ & $7.1 / 13.3$ & $7.6 / 13.4$ \\
& $\mathbf{M}_{\mathbf{1}} / \mathbf{M}_{\mathbf{2}}(\boldsymbol{v} / \boldsymbol{v})$ & $0.079 / 0.369$ & $0.085 / 0.416$ & $0.009 / 0.246$ & $0.018 / 0.263$ \\
\hline \multirow{4}{*}{$1950-1983$} & $r$ & 0.29 & 0.36 & 0.32 & 0.26 \\
& $\mathbf{T}_{\mathbf{1}} / \mathbf{T}_{\mathbf{2}}\left({ }^{\circ} \mathbf{C}\right)$ & $2.5 / 12.9$ & $3.6 / 10.9$ & $5.4 / 15.4$ & $6.7 / 13.7$ \\
& $\mathbf{M}_{\mathbf{1}} / \mathbf{M}_{\mathbf{2}}(\boldsymbol{v} / \boldsymbol{v})$ & $0.065 / 0.460$ & $0.081 / 0.462$ & $0.045 / 0.101$ & $0.027 / 0.111$ \\
\hline \multirow{3}{*}{$1984-2016$} & $r$ & 0.45 & 0.36 & 0.60 & 0.49 \\
& $\mathbf{T}_{\mathbf{1}} / \mathbf{T}_{\mathbf{2}}\left({ }^{\circ} \mathbf{C}\right)$ & $2.6 / 17.5$ & $3.2 / 11.7$ & $6.66 / 13.6$ & $8.67 / 15.3$ \\
& $\mathbf{M}_{\mathbf{1}} / \mathbf{M}_{\mathbf{2}}(\boldsymbol{v} / \boldsymbol{v})$ & $0.094 / 0.216$ & $0.069 / 0.477$ & $0.014 / 0.219$ & $0.077 / 0.267$ \\
\hline
\end{tabular}


The monthly growth response to temperature $(g T)$ and soil moisture $(g M)$ increased in Q. frainetto and $Q$. canariensis since the 1950s, mainly for spring and autumn, due to lower soil water availability and a significant rise in temperatures of both seasons (Figure 7). The estimated period with soil moisture limitations $(g M<g T)$ increased faster in Q. frainetto after the 1980s and in Q. canariensis after the 1990s, with hotter climate conditions during the beginning of the growing season, these hotter and drier conditions being more evident in $\mathrm{D}$ than ND trees for both tree species.

\section{Discussion}

\subsection{Climate Variability and Growth Trends}

The studied deciduous oak forests have experienced a rise in air temperature since the 1970s, with warmer and drier spring-summer conditions during the 1980s (Q. frainetto) and 1990s (Q. canariensis) (Figure 2), together with the occurrence of severe droughts in the 1990s and 2000s which triggered dieback episodes in both sites $[5,14,15]$. The abrupt warming leading to climate aridification differentially affected D and ND trees regarding the growth responses to climate and probably in their xylem and leaf phenology [52]. These results seem to indicate a growth constraint after the climate shift towards warmer and drier early springs, and match with previous studies showing a growth decline after the 1990s with cascading effects for dieback symptoms characterized by shoot and leaf shedding, reduced growth rates, and high mortality rates $[5,27]$. Our study suggests that drier and warmer conditions will cause a growth reduction (Figure 3) in deciduous oak species growing in seasonally drought-prone Mediterranean regions because of increasingly warmer and drier winter to spring conditions $[15,18,25]$. Our simulations also indicate that these constraining conditions could occur earlier if the climate continues warming.

In Q. frainetto D and ND tress did not show different growth rates prior to the 1980s. In contrast, Q. canariensis ND trees showed higher growth rates than D trees during wet decades (1970s) (Figure 3). The D trees in both species showed lower growth rates than ND trees after the 1990s shift towards warm-dry conditions in agreement with previous studies indicating lower growth rates preceding death in recently dead trees [27]. According to our results, the uncoupled growth trends between D and ND trees since the 1990s could indicate that warmer and drier early growing-season conditions are associated with dieback and growth decline [53]. This recent shift in growth trends indicate that slow-growing oak trees were more prone to show dieback, possibly because they presented a poor stomatal regulation which did not avoid the excessive water loss through leaves and impaired their water-gas exchange dynamics $[14,52,54]$. However, other studies in deciduous temperate oaks as Q. robur showed that $\mathrm{D}$ trees grew more in the past than ND trees suggesting that trees growing vigorously and producing vessels of wider lumen may be also more prone to xylem embolism [32].

\subsection{Warmer and Drier Conditions during the Early Growing Season Reduce Growth in D Trees}

Our results showed negative growth responses to rising temperatures in both oak species (Figure 4), but such responses significantly varied with canopy dieback, see also [2,5,52]. These findings point out that an extended growing season due to warmer late winter and early spring conditions could have enhanced growth of oaks as long as there is no soil water restriction [55-57] (Figures 4 and 5). However, D individuals present a more tight coupling to growing-season temperatures than ND trees (Figure 4), as we hypothesized, suggesting they are more vulnerable to the rising evapotranspiration rates. It is noticeable that in the case of $\mathrm{D} Q$. canariensis trees growth negatively responded to warmer previous autumn, suggesting consumption of stored sugars due to cumulative drought stress [26], whereas declining $Q$ frainetto growth responded more to warm early spring temperatures when growth resumption occurs (Figure 5). These differences could explain the vulnerability to hotter drought of both ring-porous oaks [58] since we detected the most marked increase in temperatures mainly during spring in $Q$. frainetto and during spring and autumn in Q. canariensis forests. We also found that radial growth is enhanced by wet spring conditions in $Q$. canariensis, this correlation being higher 
in D than ND trees, by a wet previous winter in $Q$. frainetto; and by a wet previous autumn in both species, affecting soil water availability and probably the storage and mobilization of non-structural carbohydrates [57]. Climate-growth associations were stronger in ND than in D trees, particularly in $Q$. canariensis (Figure 4). In the case of $Q$. frainetto, the possible effect of prior winter precipitation on growth can be explained by the recharge of soil water reserves during this season since these study areas are characterized by shallow and rocky soils with low soil water holding capacity [5,14]. The higher responsiveness to inter-annual variability of winter precipitation of ND trees as compared to D trees corresponds to the contrasting vulnerability between vigor status regarding the anisohydric behavior of these species, since the development of earlywood vessels are more related with prior winter climate [15], whereas the latewood formation is limited by current spring to summer cumulative water deficit $[22,58,59]$. This stronger response of $\mathrm{D}$ trees to the warmer and drier spring-summer season after the 1980s could explain the highest sensitivity and vulnerability to recent climate shifts (Figures 5 and 7). This result suggests that higher evapotranspiration rates due to heat stress during spring could be a major trigger of dieback in similar Mediterranean, early-flushing deciduous oaks [18,26]. At the same time, warmer spring conditions seem to constrain the latewood production altering the hydraulic conductivity of these species because although the earlywood accounts for most hydraulic conductivity within the ring, many of its vessels embolize in summer $[5,20,21]$.

Interestingly, similar findings to those presented here were obtained in other winter-deciduous, Mediterranean oak species with ring-porous wood such as $Q$. faginea [14,20,21,54]. For instance, D trees of those two species responded more to spring water availability because they need to form a new ring of functional xylem before budburst in order to match its high spring water requirements to form new foliage, and such water demand is increasing with a climate shift towards warmer conditions [20,54]. Overall, water shortage during spring and summer causes a severe reduction of latewood production in ring-porous Mediterranean oak species [59], which might increase their susceptibility to further water deficit if some earlywood vessels lose functionality due to drought-induced cavitation in spring [21]. On the other hand, the positive impact of previous-year precipitation on ND trees of both species may indicate that those trees start forming xylem earlier and have an earlier onset of shoot and leaf development than D trees [59].

However, positive growth responses of Q. canariensis to previous late summer and autumn conditions may also indicate premature leaf withering and shoot shedding to reduce respiration costs, consequently affecting next spring growth or causing lagged growth responses to late-winter climate conditions [55]. This reduction in carbon gain has been linked to xylem hydraulic failure [60]. In addition, initial phenotypic or genetic differences together with site-specific soil conditions and large belowground competition for water and nutrients between neighboring oaks could increase the vulnerability to drought, since trees with deeper root systems are able to use different soil water sources under drought stress [61]. For instance, variability in tree size could explain the observed differences in growth and responses to climate in Q. frainetto and Q. canariensis, respectively. The ring formation in Mediterranean ring-porous species is very dependent on the prior winter water supply, and also on previous temperature and photosynthetic activity that may uncouple under changing climate and/or in response to extreme droughts [15]. Therefore, comparative xylogenesis, physiological and morphological studies between D and ND trees are needed to unravel the mechanisms underlying contrasting mortality in Mediterranean drought-prone oaks forests, cf. [54]. Furthermore, the physiological ability of oaks to cope with changing environmental conditions, including the interaction between climate and the legacy effects of past forest management could influence the long-term growth responses to drought [62]. Although the studied forests have not been recently managed, their past historical use could influence the long-term responses to recent hotter droughts. In this sense, our results allow novel knowledge to establish vulnerability thresholds to drought and adapt management measures to improve the resilience of Mediterranean oak ecosystems, cf. [18]. 


\subsection{Changes in the Climatic Thresholds Leading to Forest Dieback}

We found a longer dry season limitation $(g M<g T)$ and hotter conditions (higher $g T$ ) affecting the growth of $\mathrm{D}$ trees of both species several decades before the growth decline started or the climate-growth shifts occurred. By exceeding its functional thresholds for optimum growth responses to temperature and precipitation, trees become more vulnerable to drought as observed in $Q$. frainetto (Figure 7). Differences in growth responses to climate were previously observed in other tree species $[2,49,50]$. Warmer spring temperature and increasing drought stress negatively impact the performance of drought-prone Mediterranean oaks by rising water loss through leaves [5]. ND trees could form deep and well-developed root systems in some oak species and this could explain their different growth responses to soil moisture $(g M)$ and a more efficient water use [61]. In D trees, the minimum temperature threshold of growth $\left(\mathrm{T}_{1}\right)$ and the temperature at which growth is not limited $\left(\mathrm{T}_{2}\right)$ have increased for both species after the 1990s as climate warmed and dried (Figure 7 and Table 3). In addition, the lowest percentage of soil moisture under which growth is not limited $\left(\mathrm{M}_{2}\right)$ was lower in summer than in spring (Figure 6), suggesting a prominent role of spring water deficit to growth, thus experiencing more drought stress earlier and during a longer growing season, in agreement with other observations and projections $[2,28,50]$. This was particularly noticeable during warm-dry decades as the $1980 \mathrm{~s}$ and 1990s.

Our results showed strong long-term variations between ND and D trees regarding the functional thresholds for optimal growth responses $(g T$ and $g M)$ under warmer and drier conditions (Figure 7). In this sense, the higher evapotranspirative demand in the early growing season, when radial growth starts, constraints the wood formation by decreasing cell turgor in the xylem and the cambium and this effect may differ between D and ND trees [63] (Figure 7). Oaks display multiple structural strategies of drought resistance including adjustments of the ratio of leaf area to sapwood area, shifts in carbon allocation and storage or changes in the root system and xylem anatomy $[60,64]$. For instance, to avoid excessive negative water potential during the driest season, $Q$. canariensis and $Q$. frainetto can modify their hydraulic system when exposed to dry conditions towards smaller and less numerous earlywood vessels but increasing the density of latewood vessels $[5,14,26,65]$. However, poor xylem plasticity or acclimation to rapid temperature rises during the last decades have been evidenced as a characteristic in oaks stands showing dieback $[14,26]$.

Our findings agree with previous studies in Mediterranean oaks which found that $\mathrm{D}$ trees regulated their water status after dry and warm seasons by premature leaf withering $[60,66]$. Furthermore, anisohydric oaks species continue consuming the available nutrients and water resources and transpiring during drought, which causes bud, leaf, and fine-root mortality leading to growth reduction $[54,67]$. In this sense, $\mathrm{D}$ trees under warmer and drier conditions showed a low efficiency in water use due to excessive water loss through transpiration and growth decline [14,15]. Overall, continued growth reduction (as the one we detected in $\mathrm{D}$ trees) makes these individuals more susceptible to hotter droughts, including cascading effects on water and nutrient use [2,68]. In these symptomatic trees shifts in growth response to climate occurred decades before the onset of dieback. Our results also suggest that lower growth rates could reflect a reduction in hydraulic conductivity and carbon uptake $[68,69]$. Finally, we cannot discard that other biotic, secondary stressors as fungi, bacteria, and insects contributed to the study dieback processes [70,71]. More insight on oak dieback could be gained by linking long-term monitoring of forest phenology, biomass, and productivity changes with several functioning (growth, wood anatomy) and ecophysiological proxies (e.g., stable isotopes) in Mediterranean species $[2,5,15,72]$.

To the extent of our knowledge, this is the first study quantifying vulnerability thresholds in oak species based on a forward growth model. This approach allows identifying early-warning signals of growth shifts to long-term warmer and drier conditions. Although we used a process-based growth model and did not consider other demographic process, which should be included to model forest dynamics (regeneration, reproduction, mortality rates; see for instance [73,74]), our approach provides robust results in agreement with what has been observed in other analyses of oak dieback $[2,5,14,15,54,61,75]$. 


\section{Conclusions}

Increasingly warmer and drier conditions during the growing season triggered dieback in two Mediterranean oak species. The dieback was preceded by a growth divergence between declining and non-declining trees. This divergence occurred during dry and warm decades as the 1980s and 1990s. By using a process-based growth model we found that changes in the seasonal timing of soil water limitation triggered the long-term growth decline in trees showing higher crown defoliation. Our approach allows identifying early-warning signals of tree vulnerability by calculating growth thresholds and by quantifying shifts in the growth responses to long-term climate conditions. The presented results suggest a higher vulnerability of Mediterranean ring-porous, winter-deciduous oaks forests under projected climate warming scenarios.

Author Contributions: Conceptualization, R.S.-S., M.C. and J.J.C.; methodology, R.S.-S. and M.C.; formal analysis, R.S.-S., M.C. and J.J.C.; investigation, all authors.; resources, all authors.; data curation, all authors.; writing-original draft preparation, R.S.-S.; writing-review and editing, M.C.; L.M., F.R. and J.J.C.; project administration, F.R.; L.M.; J.J.C. and R.S.-S.; funding acquisition, F.R.; L.M.; R.S.-S. and J.J.C. All authors have read and agreed to the published version of the manuscript.

Funding: This research was financially supported by the project 'OT4CLIMA' (Italian Ministry of Education, University and Research-MIUR ARS01_00405) 'Advanced EO Technologies for studying climate change impacts on the environment' and by the FORMAL (RTI2018-096884-B-C31) and LESENS (RTI2018-096884-B-C33) projects from the Spanish Ministry of Science, Innovation and Universities; VULBOS project (UPO-1263216) from the ERDF funds Andalusia regional government 2014-2020 and LM was supported by a II5B fellowship from VI-PPIT-Univ. Sevilla.

Acknowledgments: We thank M.D. Hidalgo-Gálvez for her field assistance in Gamir site and Antonio Lapolla for his field assistance in San Paolo Albanese.

Conflicts of Interest: The authors declare no conflict of interest.

\section{References}

1. Sánchez-Salguero, R.; Navarro-Cerillo, R.M.; Camarero, J.J.; Fernández-Cancio, A. Selective drought-induced decline of pine species in southeastern Spain. Clim. Chang. 2012, 113, 767-785. [CrossRef]

2. Camarero, J.J.; Gazol, A.; Sangüesa-Barreda, G.; Oliva, J.; Vicente-Serrano, S.M. To die or not to die: Early-warning signals of dieback in response to a severe drought. J. Ecol. 2015, 103, 44-57. [CrossRef]

3. Pedersen, B.S. The role of stress in the mortality of midwestern oaks as indicated by growth prior to death. Ecology 1998, 79, 79-93. [CrossRef]

4. Andersson, M.; Milberg, P.; Bergman, K.-O. Low pre-death growth rates of oak (Quercus robur L.) - Is oak death a long-term process induced by dry years? Ann. For. Sci. 2011, 68, 159-168. [CrossRef]

5. Colangelo, M.; Camarero, J.J.; Ripullone, F.; Gazol, A.; Sánchez-Salguero, R.; Oliva, J.; Redondo, M.A. Drought decreases growth and increases mortality of coexisting native and introduced tree species in a temperate floodplain forest. Forests 2018, 9, 205. [CrossRef]

6. Lindner, M.; Maroschek, M.; Netherer, S.; Kremer, A.; Barbati, A.; Garcia-Gonzalo, J.; Seidl, R.; Delzon, S.; Corona, P.; Kolstroma, M.; et al. Climate change impacts, adaptive capacity, and vulnerability of European forest ecosystems. For. Ecol. Manag. 2010, 259, 698-709. [CrossRef]

7. Allen, C.D.; Macalady, A.K.; Chenchouni, H.; Bachelet, D.; McDowell, N.; Vennetier, M.; Kitzberger, T.; Rigling, A.; Breshears, D.D.; Hogg, E.T.; et al. A global overview of drought and heat-induced tree mortality reveals emerging climate change risks for forests. For. Ecol. Manage. 2010, 259, 660-684. [CrossRef]

8. Anderegg, W.R.L.; Kane, J.; Anderegg, L.D.L. Consequences of widespread tree mortality triggered by drought and temperature stress. Nat. Clim. Chang. 2013, 3, 30-36. [CrossRef]

9. IPCC. Climate Change and Land: An IPCC special report on climate change, desertification, land degradation, sustainable land management, food security, and greenhouse gas fluxes in terrestrial ecosystems. 2019; in press.

10. Peñuelas, J.; Lloret, F.; Montoya, R. Severe drought effects on Mediterranean woody flora in Spain. For. Sci. 2001, 47, 214-218.

11. Lloret, F.; Siscart, D.; Dalmases, C. Canopy recovery after drought dieback in holm-oak Mediterranean forests of Catalonia (NE Spain). Glob. Chang. Biol. 2004, 10, 2092-2099. [CrossRef] 
12. Di Filippo, A.; Alessandrini, A.; Biondi, F.; Blasi, S.; Portoghesi, L.; Piovesan, G. Climate change and oak growth decline: Dendroecology and stand productivity of a Turkey oak (Quercus cerris L.) old stored coppice in Central Italy. Ann. For. Sci. 2010, 67, 706. [CrossRef]

13. Linares, J.C.; Camarero, J.J. From pattern to process: Linking intrinsic water-use efficiency to drought-induced forest decline. Glob. Chang. Biol. 2012, 18, 1000-1015. [CrossRef]

14. Colangelo, M.; Camarero, J.J.; Battipaglia, G.; Borghetti, M.; De Micco, V.; Gentilesca, T.; Ripullone, F. A multi-proxy assessment of dieback causes in a Mediterranean oak species. Tree Physiol. 2017, 37, 617-631. [CrossRef]

15. Colangelo, M.; Camarero, J.J.; Borghetti, M.; Gazol, A.; Ripullone, F. Size matters a lot: Drought-affected Italian oaks are smaller and show lower growth prior to tree death. Front. Plant Sci. 2017, 8, 135. [CrossRef]

16. Sangüesa-Barreda, G.; Camarero, J.J.; Oliva, J.; Montes, F.; Gazol, A. Past logging, drought and pathogens interact and contribute to forest dieback. Agric. For. Meteorol. 2015, 208, 85-94. [CrossRef]

17. Barbero, M.; Loisel, R.; Quèzel, P. Biogeography, ecology and history of Mediterranean Quercus ilex ecosystems. Vegetatio 1992, 99-100, 19-34. [CrossRef]

18. Gentilesca, T.; Camarero, J.J.; Colangelo, M.; Nolè, A.; Ripullone, F. Drought-induced oak decline in the western Mediterranean region: An overview on current evidences, mechanisms and management options to improve forest resilience. iFor. Biogeosci. For. 2017, 10, 796-806. [CrossRef]

19. Adams, H.D.; Zeppel, M.J.; Anderegg, W.R.; Hartmann, H.; Landhäusser, S.M.; Tissue, D.T.; Huxman, T.E.; Hudson, P.J.; Franz, T.E.; Allen, C.D.; et al. A multi-species synthesis of physiological mechanisms in drought-induced tree mortality. Nat. Ecol. Evol. 2016, 1, 1285-1291. [CrossRef]

20. Corcuera, L.; Camarero, J.J.; Gil-Pelegrín, E. Effects of a severe drought on growth and wood-anatomical properties of Quercus faginea. IAWA J. 2004, 25, 185-204. [CrossRef]

21. Corcuera, L.; Camarero, J.J.; Gil-Pelegrín, E. Effects of a severe drought on Quercus ilex radial growth and xylem anatomy. Trees 2004, 18, 83-92.

22. Montserrat-Martí, G.; Camarero, J.J.; Palacio, S.; Pérez-Rontomé, C.; Milla, R.; Albuixech, J.; Maestro, M. Summer-drought constrains the phenology and growth of two co-existing Mediterranean oaks with contrasting leaf habit: Implications for their persistence and reproduction. Trees 2009, 23, 787-799. [CrossRef]

23. McDowell, N.; Williams, A.; Xu, C.; Pockman, W.T.; Dickman, L.T.; Sevanto, S.; Pangle, R.; Limousin, J.; Plaut, J.; Mackay, D.S.; et al. Multi-scale predictions of massive conifer mortality due to chronic temperature rise. Nat. Clim. Chang. 2016, 6, 295-300. [CrossRef]

24. Greenwood, S.; Ruiz-Benito, P.; Martınez-Vilalta, J.; Lloret, F.; Kitzberger, T.; Allen, C.D.; Kraft, N.J. Tree mortality across biomes is promoted by drought intensity, lower wood density and higher specific leaf area. Ecol. Lett. 2017, 20, 539-553. [CrossRef]

25. Tessier, L.; Nola, P.; Serre-Bachet, F. Deciduous Quercus in the Mediterranean region-Tree-ring/climate relationships. New Phytol. 1994, 126, 355-367. [CrossRef]

26. Gea-Izquierdo, G.; Fonti, P.; Cherubini, P.; Martín-Benito, D.; Chaar, H.; Cañellas, I. Xylem hydraulic adjustment and growth response of Quercus canariensis Willd. to climatic variability. Tree Physiol. 2012, 32, 401-403. [CrossRef]

27. Cailleret, M.; Jansen, S.; Robert, E.M.R.; Desoto, L.; Aakala, T.; Antos, J.A.; Beikircher, B.; Bigler, C.; Bugmann, H.; Caccianiga, M.; et al. A synthesis of radial growth patterns preceding tree mortality. Glob. Chang. Biol. 2017, 23, 1675-1690. [CrossRef]

28. Sánchez-Salguero, R.; Camarero, J.J. Greater sensitivity to hotter droughts underlies juniper dieback and mortality in Mediterranean shrublands. Sci. Total Environ. 2020. [CrossRef]

29. Vaganov, E.A.; Hughes, M.K.; Shashkin, A.V. Growth Dynamics of Conifer Tree Rings; Springer: Berlin, Germany, 2006; p. 358. ISBN 978-3-540-26086-8.

30. Tolwinski-Ward, S.E.; Evans, M.N.; Hughes, M.K.; Anchukaitis, K.J. An efficient forward model of the climate controls on interannual variation in tree-ring width. Clim. Dyn. 2011, 36, 2419-2439. [CrossRef]

31. Tolwinski-Ward, S.E.; Anchukaitis, K.J.; Evans, M.N. Bayesian parameter estimation and interpretation for an intermediate model of tree-ring width. Clim. Past 2013, 9, 1481-1493. [CrossRef]

32. Levanic, T.; Cater, M.; McDowell, N.G. Associations between growth, wood anatomy, carbon isotope discrimination and mortality in a Quercus robur forest. Tree Physiol. 2011, 31, 298-308. [CrossRef] [PubMed] 
33. Chatziphilippidis, G.; Spyroglou, G. Sustainable Management of Coppice Forests in Greece. In Towards the Sustainable Use of Europe's Forest Ecosystem and Landscape Research: Scientific Challenges and Opportunities Proc 25-27 June 2003 Tours; Anderson, F., Birot, Y., Pāivinen, R., Eds.; EFI Proceedings: Joensuu, Finland, 2004; Volume 49, pp. 61-70.

34. Sanders, T.G.M.; Pitman, R.; Broadmeadow, M.S.J. Species-specific climate response of oaks (Quercus spp.) under identical environmental conditions. iFor. Biogeosci. For. 2004, 7, 61-69. [CrossRef]

35. Costa, M.; Morla, C.; Sáinz, H. Los Bosques Ibéricos: Una Interpretación Geobotánica; Editorial Planeta: Barcelona, Spain, 1997; p. 598.

36. Cornes, R.C.; Van der Schrier, G.; Van den Besselaar, E.J.; Jones, P.D. An Ensemble Version of the E-OBS Temperature and Precipitation Datasets. J. Geophys. Res. Atmos. 2018, 123, 9391-9409. [CrossRef]

37. Wazen, N.; Garavaglia, V.; Picard, N.; Besacier, C.; Fady, B. Distribution maps of twenty-four Mediterranean and European ecologically and economically important forest tree species compiled from historical data collections. Ann. Silvicul. Res. 2020, 44, 95-101.

38. Bordács, S.; Zhelev, P.; Schirone, B. EUFORGEN Technical Guidelines for genetic conservation and use for Hungarian oak (Quercus frainetto). In European Forest Genetic Resources Programme (EUFORGEN); European Forest Institute: Rome, Italy, 2019; p. 6.

39. Dobbertin, M. Tree growth as indicator of tree vitality and of tree reaction to environmental stress: A review. Eur. J. For. Res. 2005, 124, 319-333. [CrossRef]

40. Fritts, H.C. Tree Rings and Climate; Academic Press: London, UK, 2001; p. 567.

41. Holmes, R.L. Computer-assisted quality control in tree-ring dating and measurement. Tree Ring Bull. 1983, 43, 69-78.

42. Briffa, K.R.; Jones, P.D. Basic chronology statistics and assessment. In Methods of Dendrochronology: Applications in the Environmental Sciences; Kluwer Academic Publishers: Berlin, Germany, 1990; pp. 137-152.

43. Wigley, T.M.L.; Briffa, K.R.; Jones, P.D. On the average value of correlated time series, with applications in dendroclimatology and hydrometeorology. J. Clim. Appl. Meteorol. 1984, 23, 201-213. [CrossRef]

44. Bunn, A.G. A dendrochronology program library in $r(d p l R)$. Dendrochronologia 2008, 26, 115-124. [CrossRef]

45. Zang, C.; Biondi, F. Treeclim: An R package for the numerical calibration of proxy-climate relationships. Ecography 2015, 38, 431-436. [CrossRef]

46. R Development Core Team. R: A Language and Environment for Statistical Computing; R Foundation for Statistical Computing: Vienna, Austria, 2020.

47. Huang, J.; Van den Dool, H.M.; Georgakakos, K.P. Analysis of model-calculated soil moisture over the United States (1931-1993) and applications to long-range temperature forecasts. J. Clim. 1996, 9, 1350-1362. [CrossRef]

48. Lavergne, A.; Daux, V.; Villalba, R.; Barichivich, J. Temporal changes in climatic limitation of tree-growth at upper treeline forests: Contrasted responses along the west-to-east humidity gradient in Northern Patagonia. Dendrochronologia 2015, 36, 49-59. [CrossRef]

49. Sánchez-Salguero, R.; Camarero, J.J.; Gutiérrez, E.; González Rouco, F.; Gazol, A.; Sangüesa-Barreda, G.; Andreu-Hayles, L.; Linares, J.C.; Seftigen, K. Assessing forest vulnerability to climate warming using a process-based model of tree growth: Bad prospects for rear-edges. Glob. Chang. Biol. 2017, 23, 2705-2719. [CrossRef] [PubMed]

50. Sánchez-Salguero, R.; Camarero, J.J.; Carrer, M.; Gutiérrez, E.; Alla, A.Q.; Andreu-Hayles, L.; Hevia, A.; Koutavas, A.; Martínez-Sancho, E.; Nola, P.; et al. Climate extremes and predicted warming threaten Mediterranean Holocene firs forests refugia. Proc. Natl. Acad. Sci. USA 2017, 114, E10142-E10150. [CrossRef] [PubMed]

51. Zeng, X.; Wei, C.; Liu, X.; Zhang, L. Qinghai spruce (Picea crassifolia) and Chinese pine (Pinus tabuliformis) show high vulnerability and similar resilience to early-growing-season drought in the Helan Mountains, China. Ecol. Indic. 2020, 110, 105871. [CrossRef]

52. Camarero, J.J.; Sangüesa-Barreda, G.; Vergarechea, M. Prior height, growth, and wood anatomy differently predispose to drought-induced dieback in two Mediterranean oak species. Ann. For. Sci. 2016, 73, 341-351. [CrossRef]

53. McDowell, N.G.; Beerling, D.J.; Breshears, D.D.; Fisher, R.A.; Raffa, K.F.; Stitt, M. The interdependence of mechanisms underlying climate-driven vegetation mortality. Trends Ecol. Evol. 2011, 26, 523-532. [CrossRef] 
54. Zweifel, R.; Rigling, A.; Dobbertin, M. Species-specific stomatal response of trees to drought-A link to vegetation dynamics? J. Veg. Sci. 2009, 20, 442-454. [CrossRef]

55. Villar, R.; Ruiz-Benito, P.; Enrique, G.; Poorter, H.; Cornelissen, J.H.; Quero, J.L. Growth and growth-related traits for a range of Quercus species grown as seedlings under controlled conditions and for adult plants from the field. In Oaks Physiological Ecology. Exploring the Functional Diversity of Genus Quercus L.; Gil-Pelegrín, E., Peguero-Pina, J.J., Sancho-Knapik, D., Eds.; Springer: Cham, Switzerland, 2017; pp. 393-417.

56. Forner, A.; Valladares, F.; Bonal, D.; Granier, A.; Grossiord, C.; Aranda, I. Extreme droughts affecting Mediterranean tree species' growth and water-use efficiency: The importance of timing. Tree Physiol. 2018, 38, 1127-1137. [CrossRef]

57. Gričar, J.; Zavadlav, S.; Jyske, T.; Lavrič, M.; Laakso, T.; Hafner, P.; Eler, K.; Vodnik, D. Effect of soil water availability on intra-annual xylem and phloem formation and non-structural carbohydrate pools in stem of Quercus pubescens. Tree Physiol. 2019, 39, 222-233. [CrossRef]

58. Corcuera, L.; Camarero, J.J.; Sisó, S.; Gil-Pelegrín, E. Radial-growth and wood-anatomical changes in overaged Quercus pyrenaica coppice stands: Functional responses in a new Mediterranean landscape. Trees 2006, 20, 91-98. [CrossRef]

59. Alla, A.Q.; Camarero, J.J. Contrasting responses of radial growth and wood anatomy to climate in a Mediterranean ring-porous oak: Implications for its future persistence or why the variance matters more than the mean. Eur. J. For. Res. 2012, 131, 1537-1550. [CrossRef]

60. Peguero-Pina, J.J.; Sancho-Knapik, D.; Martín, P.; Saz, M.A.; Gea-Izquierdo, G.; Cañellas, I.; Gil-Pelegrín, E. Evidence of vulnerability segmentation in a deciduous Mediterranean oak (Quercus subpyrenaica E. H. del Villar). Trees 2015, 29, 1917-1927. [CrossRef]

61. Ripullone, F.; Camarero, J.J.; Colangelo, M.; Voltas, J. Variation in the access to deep soil water pools explains tree-to-tree differences in drought-triggered dieback of Mediterranean oaks. Tree Physiol. 2020, 40, 591-604. [CrossRef] [PubMed]

62. Altman, J.; Hédl, R.; Szabó, P.; Mazůrek, P.; Riedl, V.; Müllerovám, J.; Kopecký, M.; Doležal, J. Tree-rings mirror management legacy: Dramatic response of standard oaks to past coppicing in Central Europe. PLoS ONE 2013, 8, e55770. [CrossRef]

63. Cuny, H.E.; Rathgeber, C.B.K.; Lebourgeois, F.; Fortin, M.; Fournier, M. Life strategies in intra-annual dynamics of wood formation: Example of three conifer species in a temperate forest in north-east France. Tree Physiol. 2012, 32, 612-625. [CrossRef]

64. Bréda, N.; Huc, R.; Granier, A.; Dreyer, E. Temperate forest trees and stands under severe drought: A review of ecophysiological responses, adaptation processes and long-term consequences. Ann. For. Sci. 2006, 63, 625-644. [CrossRef]

65. Fichot, R.; Chamaillard, S.; Depardieu, C.; Le Thiec, D.; Cochard, H.; Barigah, T.S.; Brignolas, F. Hydraulic efficiency and coordination with xylem resistance to cavitation, leaf function, and growth performance among eight unrelated Populus deltoids $\times$ Populus nigra hybrids. J. Exp. Bot. 2011, 62, 2093-2106. [CrossRef]

66. Peguero-Pina, J.J.; Sisó, S.; Sancho-Knapik, D.; Díaz-Espejo, A.; Flexas, J.; Galmés, J.; Gil-Pelegrín, E. Leaf morphological and physiological adaptations of a deciduous oak (Quercus faginea Lam.) to the Mediterranean climate: A comparison with a closely related temperate species (Quercus robur L.). Tree Physiol. 2016, 36, 287-299. [CrossRef]

67. Palacio, S.; Camarero, J.J.; Maestro, M.; Alla, A.Q.; Lahoz, E.; Montserrat-Martí, G. Are storage and tree growth related? Seasonal nutrient and carbohydrate dynamics in evergreen and deciduous Mediterranean oaks. Trees 2018, 32, 777-790. [CrossRef]

68. Poorter, L.; Castilho, C.V.; Schietti, J.; Oliveira, R.S.; Costa, F.R.C. Can traits predict individual growth performance? A test in a hyperdiverse tropical forest. New Phytol. 2018, 219, 109-121. [CrossRef]

69. Magnani, F.; Mencuccini, M.; Grace, J. Age-related decline in stand productivity: The role of structural acclimation under hydraulic constraints. Plant Cell Environ. 2000, 23, 251-263. [CrossRef]

70. Manion, P.D. Tree Disease Concepts; Prentice Hall: Upper Saddle River, NJ, USA, 1981; p. 409.

71. Gómez-Aparicio, L.; García-Valdés, R.; Ruiz-Benito, P.; Zavala, M.A. Disentangling the relative importance of climate, size and competition on tree growth in Iberian forests: Implications for forest management under global change. Glob. Chang. Biol. 2011, 17, 2400-2414. [CrossRef]

72. Drobyshev, I.; Linderson, H.; Sonesson, K. Relationship between crown condition and tree diameter growth in southern Swedish oaks. Environ. Monit. Assess. 2007, 128, 61-73. [CrossRef] [PubMed] 
73. Matías, L.; Abdelaziz, M.; Godoy, O.; Gómez-Aparicio, L. Disentangling the climatic and biotic factors driving changes in the dynamics of Quercus suber populations across the species' latitudinal range. Divers. Distrib. 2019, 25, 524-535. [CrossRef]

74. Matías, L.; Pérez-Ramos, I.M.; Gómez-Aparicio, L. Are northern-edge populations of cork oak more sensitive to drought than those of the southern-edge? Environ. Exp. Bot. 2019, 163, 78-85. [CrossRef]

75. Rodríguez-Calcerrada, J.; Sancho-Knapik, D.; Martin-StPaul, N.K.; Limousin, J.-M.; McDowell, N.C.; Gil-Pelegrín, E. Drought-Induced Oak Decline-Factors Involved, Physiological Dysfunctions, and Potential Attenuation by Forestry Practices. In Oaks Physiological Ecology. Exploring the Functional Diversity of Genus Quercus L.; Gil-Pelegrín, E., Peguero-Pina, J.J., Sancho-Knapik, D., Eds.; Springer: Cham, Switzerland, 2017; pp. 393-417.

(C) 2020 by the authors. Licensee MDPI, Basel, Switzerland. This article is an open access article distributed under the terms and conditions of the Creative Commons Attribution (CC BY) license (http://creativecommons.org/licenses/by/4.0/). 